\title{
How to Overcome Antiviral-Resistant Hepatitis B Virus?
}

\author{
Byung-Cheol Song \\ Department of Internal Medicine, Jeju National University School of Medicine, Jeju, Korea
}

\section{Key Words}

Antiviral resistance $\cdot$ Chronic hepatitis $B \cdot$ Combination

therapy $\cdot$ Nucleoside/nucleotide analogs

\begin{abstract}
The goal of antiviral therapy in patients with chronic hepatitis $B$ is long-lasting suppression of hepatitis $B$ virus (HBV) DNA, normalization of serum alanine aminotransferase and prevention of progression of chronic liver disease to liver cirrhosis, hepatocellular carcinoma and death. Even though substantial advances have been made in the treatment of chronic hepatitis $B$ in the past decade with the use of oral nucleoside/nucleotide analogs, emergence of antiviral resistance is the most important factor in treatment failure for chronic hepatitis B. Herein, we will discuss how to prevent antiviral resistance.

Copyright $\odot 2010$ S. Karger AG, Basel
\end{abstract}

\section{Introduction}

The goal of antiviral therapy in patients with chronic hepatitis $\mathrm{B}(\mathrm{CHB})$ is long-lasting suppression of HBV DNA, normalization of serum alanine aminotransferase (ALT) and eventually prevention of progression of chronic liver disease to liver cirrhosis, hepatocellular carcinoma (HCC) and death [1]. Over the past decade, remark- able progress has been made in understanding the natural course of hepatitis $B$ virus (HBV) infection and also in the treatment for $\mathrm{CHB}$ [2-4].

Table 1 summarizes the antiviral efficacy of available antiviral agents. The nucleoside/nucleotide analogs (NAs) are very effective in suppressing HBV replication, and are well tolerated and safe. Thus, they have been widely used as the primary therapeutic agents. However, the treatment requires a long-term administration of these NAs, which in some cases must continue indefinitely [1-12]. Unfortunately, long-term therapy with NAs is associated with the development of antiviral drug resistance, which negates the effect of antiviral agents [5, 13-15]. Therefore, the emergence of drug resistance becomes a major challenge in the era of NA therapy. Figure 1 summarizes the rate of antiviral resistance.

This review will focus on how to prevent antiviral resistance and how to treat the patients with drug resistance to prevent further resistance.

\section{Association between the Progression of Chronic HBV and Serum HBV DNA Levels}

The large prospective community-based Risk Evaluation Viral Load Elevation and Associated Liver Disease (REVEAL) study of 3,653 HBsAg-positive individuals clearly demonstrated that the incidence of liver cirrhosis

\section{KARGER \\ Fax +41 613061234 \\ E-Mail karger@karger.ch}

www.karger.com
(ㄷ) 2010 S. Karger AG, Basel

0300-5526/10/0531-0029\$26.00/0

Accessible online at:

www.karger.com/int
Byung-Cheol Song, MD

Department of Internal Medicine

Jeju National University School of Medicine

1753-3 Ara-dong, Jeju 690-716 (Republic of Korea)

Tel. +82 64717 1582, Fax +82 64717 1131, E-Mail drsong@jejunu.ac.kr 
Fig. 1. Cumulative genotypic antiviral resistance in patients with chronic hepatitis B. LMV = Lamivudine; $\mathrm{LdT}=$ telbivudine; $\mathrm{ADV}=$ adefovir; $\mathrm{ETV}=$ entecavir; $\mathrm{TDF}=$ tenofovir. Data from [16-19, 22, 30, 31, 47, $54,67,74]$.

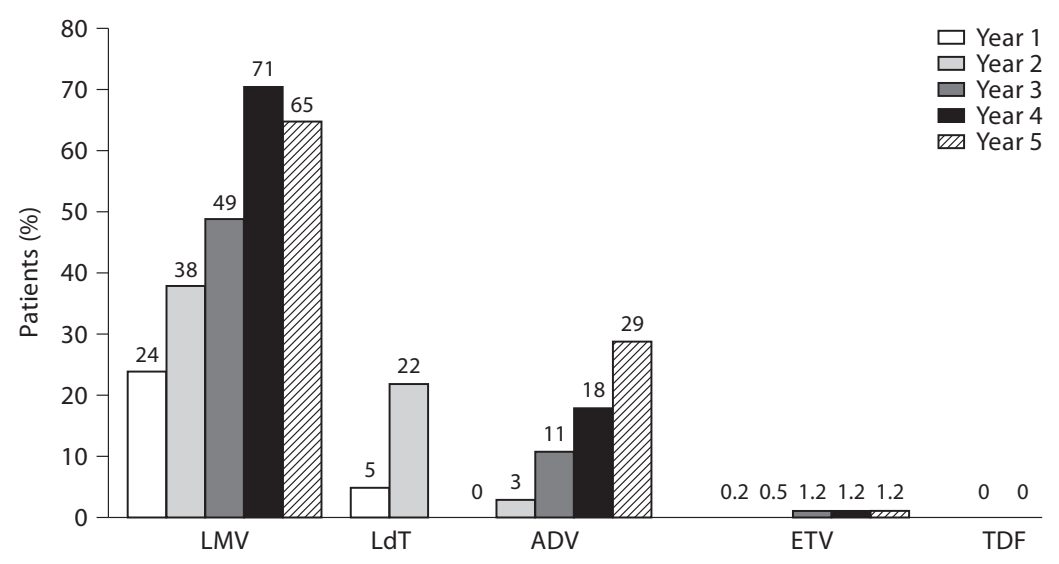

Table 1. Percentage response rate to approved antiviral therapy in patients with chronic hepatitis B at 1 year

Peginterferon Lamivudine Emtricitabine Telbivudine Adefovir Entecavir Tenofovir

HBeAg-positive patients

Undetectable HBV DNA by PCR-based assays

HBeAg loss

Normalization of ALT

Histologic improvement

HBeAg-negative patients

Undetectable HBV DNA by PCR-based assays

Normalization of ALT

Histologic improvement

$\begin{array}{ll}25 & 39 \\ 30 & 22 \\ 39 & 66 \\ 38 & 59\end{array}$

$\begin{array}{ll}39 & 39 \\ 22 & 14 \\ 66 & 65 \\ 59 & 62\end{array}$

$39 \quad 60$

$\begin{array}{llll}60 & 21 & 67 & 76\end{array}$

$\begin{array}{lllll}14 & 26 & 24 & 22 & 21^{\text {a }}\end{array}$

$65 \quad 77$

$62 \quad 65$

48

53

68

68
72

68

74

$\begin{array}{lllllll}63 & 72 & 79 & 88 & 51 & 90 & 93 \\ 38 & 74 & 65 & 74 & 72 & 78 & 76 \\ 48 & 63 & 59 & 66 & 64 & 70 & 72\end{array}$

Adapted from references [16, 19-22, 70-72]. ${ }^{a} \mathrm{HBeAg}$ seroconversion.

and the development of HCC increased progressively in a direct relationship with HBV DNA levels at study entry $[2,4]$. In particular, HBV DNA levels of $4 \log _{10}$ copies $/ \mathrm{ml}$ or greater were associated with a significant risk for cirrhosis and the development of HCC [2, 4]. The study also showed that patients with increasing levels of HBV DNA over time or with persistently increased levels during follow-up evaluation had the highest risk of HCC. In contrast, lowering of HBV DNA levels from the highest points was linked with a reduction in risk of HCC only when HBV DNA decreased to less than $4 \log _{10}$ copies $/ \mathrm{ml}$ [2]. However, in a recent subanalysis of the REVEAL cohort, a viral titer lower than $4 \log _{10}$ copies/ml does not seem to be safe enough to prevent the development of HCC. Iloeje et al. [3] found that individuals with levels of
HBV DNA lower than $4 \log _{10}$ copies/ml have a 4 -fold increased risk for liver-cancer related mortality, compared with uninfected (HBsAg-negative) individuals. In addition, individuals with persistently low levels of HBV DNA $\left(\geq 300\right.$ to $<4 \log _{10}$ copies $/ \mathrm{ml}$ ) had an increased risk of developing HCC, compared with patients whose HBV DNA levels were persistently undetectable ( $<300$ copies $/ \mathrm{ml})$.

$\mathrm{CHB}$ patients whose HBV DNA were persistently suppressed with antiviral agents provided compelling evidence that reduction of HBV DNA levels improves histological and clinical outcomes [16-23]. In a review of 26 prospective clinical trials, there were strong correlations between the reduction of serum HBV DNA level on treatment and histological improvement [24]. In lamivudineresistant decompensated cirrhotic patients, treatment 
with adefovir improved Child-Pugh scores [25]. In addition, long-term treatment with lamivudine in $\mathrm{CHB}$ patients reduces the progression of liver disease, with lower frequency of hepatic decompensation, fewer episodes of spontaneous bacterial peritonitis and esophageal variceal bleeding, and a reduced rate of HCC. These effects were especially dramatic in patients with persistent suppression of viral replication [5].

Therefore, these studies provide evidence that viral replication plays a critical role in the progression of chronic HBV infection and the development of HCC, thus convincingly establishing a rationale for antiviral therapy to suppress HBV DNA completely in a sustained manner.

\section{Nomenclature of Antiviral Resistance}

At the 2006 National Institute of Health Workshop on $\mathrm{HBV}$, standardizing the nomenclature of antiviral resistance was proposed (table 2) [10, 26, 27].

Primary treatment failure (non-response) is defined as the inability of NAs to reduce serum HBV DNA to $\geq 1$ $\log _{10} \mathrm{IU} / \mathrm{ml}$ after the first 6 months of treatment. Primary treatment failure may be related to host, viral and drug factors. Polymorphism of host enzymes that are involved in converting prodrugs to their active compound or phosphorylating NAs to their triphosphate may contribute to primary treatment failure [28]. The potency of the antiviral agents might be important. Primary treatment failure was frequently reported in patients taking adefovir but not entecavir or tenofovir, which are 2 very potent antiviral agents. Suboptimal dose of adefovir $10 \mathrm{mg}$ might be associated with primary treatment failure [21]. Monitoring of primary treatment failure is an indication to change antiviral agents because residual viral levels after 6-12 months of therapy increased the risk of antiviral resistance [19, 29-32].

Virologic breakthrough or secondary treatment failure is defined as an increase in serum HBV DNA by $\geq 1$ $\log _{10} \mathrm{IU} / \mathrm{ml}$ above nadir on 2 or more consecutive occasions at least 1 month apart on treatment after achieving an initial response in compliant patients. This is the first clinical evidence of the development of antiviral resistance [26]. Serum HBV DNA levels initially tended to be low because most antiviral resistant mutants have a low replication fitness compared with wild-type virus. However, with time compensatory mutations, such as rtL80I/ $\mathrm{V}, \mathrm{rtL} 180 \mathrm{M}, \mathrm{rtV} 173 \mathrm{~L}$ in lamivudine-resistant patients, develop and restore the replication fitness, so enabling
Table 2. Nomenclature for antiviral resistance $[10,26,27]$

\begin{tabular}{ll}
\hline Term & Definition \\
\hline $\begin{array}{l}\text { Primary treat- } \\
\text { ment failure } \\
\text { (non-response) }\end{array}$ & $\begin{array}{l}\text { Inability of nucleoside/nucleotide analog treat- } \\
\text { ment to reduce serum HBV DNA by } \geq 2 \log _{10}\end{array}$ \\
\hline $\begin{array}{l}\text { Secondary treat- } \\
\text { ment failure } \\
\text { (virologic }\end{array}$ & $\begin{array}{l}\text { Increase in serum HBV DNA by } \geq 1 \log _{10} \text { above } \\
\text { nadir on } \geq 2 \text { occasions } 1 \text { month apart, while on } \\
\text { treatment, after achieving initial response in a }\end{array}$ \\
\hline
\end{tabular}

Viral rebound Increase in serum HBV DNA to $\geq 20,000 \mathrm{IU} / \mathrm{ml}$ or above pretreatment level after achieving virologic response, during continued treatment.

Biochemical Elevation in serum ALT while on treatment, breakthrough after achieving normalization in a medicationcompliant patient.

Genetic barrier Threshold probability that the virus will mutate and escape from the selective action of the drug, thereby making the virus resistant to specific drug. Number of amino acid substitutions needed for development of primary antiviral drug resistance.

Genotypic Detection of viral populations bearing amino resistance acid substitutions in the reverse transcriptase region of the $\mathrm{HBV}$ genome that have been shown to confer resistance to antiviral drugs in phenotypic assay, during antiviral therapy. These mutations are usually detected in patients with virologic breakthrough but they can also be present in patients with persistent viremia and no virologic breakthrough.

Phenotypic Decreased susceptibility of an HBV polymerase resistance to an antiviral treatment in vitro.

Cross resistance Decreased susceptibility to more than 1 antiviral drug conferred by the same amino acid substitution or combination of amino acid substitutions.

the mutant virus to replicate at near wild-type levels [3335 . Eventually, the viral load during continuous treatment returns to and sometimes exceeds pretreatment levels $[33,36]$.

Biochemical breakthrough is defined as an elevation in serum ALT level while on treatment after achieving normalization in compliant patients. Biochemical breakthrough usually lags behind virologic breakthrough, and serum ALT levels may remain normal for weeks to years after the development of antiviral resistance [37-39]. 
Genotypic resistance refers to the detection of viral population bearing amino acid substitution in the reverse transcriptase region of the HBV genome that has been shown to confer resistance to antiviral drugs in a phenotypic assay during NA therapy. These mutations are usually detected in patients with virologic breakthrough but they can also be present at low levels in patients whose virus levels plateau [40].

\section{Mechanism of Antiviral Resistance}

HBV has a partially double-stranded 3.2-kb genome. Although HBV is a DNA virus, replication of viral DNA occurs via an RNA intermediate [41]. HBV has a high rate of replication, with $10^{11}$ virions produced per day [42]. However, reverse transcriptase in the polymerase of HBV lacks a proofreading function; therefore, there is a high mutational rate of approximately $1.4-3.2 \times 10^{-5}$ nucleotide substitutions per site per year. This rate is approximately 10 -fold higher than that for other DNA viruses [43]. This enormous daily production, coupled with the high mutational rate, equals at least $10^{10}$ point mutations produced per day in individuals who have a high level of replication [43]. Thus, it is possible that all nucleotide changes in the whole HBV genome can be produced each day. However, the organization of the open reading frame in a frame-shifted overlapping arrangement within the HBV genome does place some restriction on the final number of viable mutations that are actually generated.

The stability of the predominant HBV within the virus pool is maintained by particular selection pressures from the host's immune system and the viability and replication competence of the virus [43]. Under selection pressure generated by the presence of an antiviral agent, viruses with a mutation that confers a replication advantage are selected and eventually become the predominant viral species [40].

Several factors are associated with the development of antiviral resistance, but the key ones - based on our current understanding - are potency, viral fitness, the genetic barrier of the antiviral agent, and patient compliance $[1,40]$.

The probability of a mutation being selected during therapy depends on the potency of antiviral agents; the probability can be depicted graphically as a bell shape [44]. Hence, a drug with low antiviral activity does not exert substantial selection pressure on the virus, and the chance of drug resistance is not high. Drugs with modest antiviral activity, such as lamivudine, result in the high- est probability of selecting drug resistance. Conversely, this likelihood becomes nil when virus replication is completely inhibited by antiviral agents because mutagenesis is replication dependent $[43,44]$.

Replication fitness refers to the ability of the virus to replicate in a defined environment. Usually, mutant viruses show less replication fitness. However, over time, compensatory mutations such as rt80, rt180 and rt173 develop after the initial primary rtM204V/I mutation, which restores functional defects in the viral polymerase caused by the primary mutations $[33-35,45]$. Even though the replication fitness of the $\mathrm{rt} 204 \mathrm{~V}$ mutant is only $10 \%$ of that of the wild type, the triple mutant, which harbors rt204, rt180 and rt173, enables the mutant virus to replicate at near wild-type levels $[33,34,45]$. Eventually, accumulation of these mutants can lead to virologic breakthrough, biochemical breakthrough and even hepatitis flare [26].

The genetic barrier, defined as the number of amino acid substitutions needed for the development of primary antiviral drug resistance, affects antiviral resistance. Antiviral agents with a high genetic barrier (e.g. entecavir) showed low resistance rates in NAs-naïve patients [46, 47]. In contrast, antiviral agents with a low genetic barrier (e.g. lamivudine or telbivudine) showed high resistance rates [1]. Pre-existing mutations can lower the genetic barrier to resistance and increase the antiviral resistance, as is the case of the presence of the rtM204V/I mutation and the subsequent development of entecavir resistance $[46,47]$.

\section{Prevention of Antiviral Resistance}

One of the most important things is to prevent antiviral resistance to avoid unnecessary treatment. Many patients with $\mathrm{CHB}$ will probably not benefit from current antiviral therapy, especially patients in the immune tolerant phase, usually manifested as normal ALT high viral load in young individuals [48]. The histological activity and grade of the liver showed minimal change [49], and the virus replication is very high in this phase. If patients in the immune tolerant phase are treated with NAs, they will have a high chance of drug resistance. Therefore, the AASLD, EASL, APASL and NIH guidelines recommend that therapy should be considered only for individuals with elevated serum ALT or more active or advanced liver disease $[1,8,10,50,51]$.

Development of drug-resistant mutants is absolutely dependent on replication, so antiviral therapy, once initi- 
ated, should aim to suppress viral replication as quickly and completely as possible. Therefore, most guidelines recommend the most potent available agents, such as entecavir or tenofovir, as the first-line therapy, or peginterferon because of absence of drug-related resistance $[1,10$, $50,51]$.

During NA therapy, the viral decay profiles usually present 2 distinct phases. Initially, there is a fast decay, corresponding to the clearance of free virus from circulation. It is followed by a slower second phase of decay, corresponding to the loss of infected cells [52]. Therefore, the degree of reduction of serum HBV DNA in this early phase reflects the potency of NAs in individuals regardless of antiviral agents.

In a study of 159 Chinese HBeAg-positive patients treated with lamivudine and followed up for a median of 29.6 months, resistance had developed in $8.3 \%$ of patients with undetectable serum HBV ( $<200$ copies/ml) by week 24. In contrast, it had developed in 59.9\% in patients with detectable HBV DNA by week 24 [53]. Similarly, in a phase III trial of 1,367 patients treated with telbivudine or lamivudine, the degree of viral suppression at week 24 was associated with clinical and virological efficacy. $\mathrm{Pa}$ tients who achieved undetectable HBV DNA levels $(<300$ copies $/ \mathrm{ml}$ ) at week 24 had a lower rate of resistance at 1 year than those who had HBV DNA levels of $\geq 4 \log _{10}$ copies/ml (2 vs. 15\%) [19]. However, in adefovir-treated patients, changes in HBV DNA at week 48 were predictors for the development of resistance [31]. In patients with HBV DNA levels less than $3 \log _{10}$ copies $/ \mathrm{ml}$ at week 48, 6\% developed resistance over 192 weeks. However, in those with HBV DNA $3 \log _{10}$ copies/ml or more at week 48, 49\% developed resistance over 192 weeks [31]. With entecavir, the week 24 on-treatment HBV DNA level during entecavir therapy in patients with lamivudine resistance was predictive of resistance at 2 years [54]. Thus, antiviral therapy should be modified at week 24 , depending on serum HBV DNA levels.

On the basis of current available data, some experts have proposed a roadmap concept [55]. For patients with complete virological response ( $<60 \mathrm{IU} / \mathrm{ml}$ or 300 copies/ $\mathrm{ml}$ at week 24), continued therapy with the same drug is recommended. In patients with partial response, defined as residual HBV DNA levels less than 2,000 IU/ml $(<4$ $\log _{10}$ copies $/ \mathrm{ml}$ ) at week 24 , who are treated with a drug with a low genetic barrier to resistance, adding an appropriate non-cross-resistant second drug is recommended to prevent the emergence of resistance and viral breakthrough. However, in patients who are treated with a drug with a high genetic barrier, they recommend con- tinuing the same drug over 48 weeks with regular monitoring of HBV DNA. In patients taking a drug with a delayed antiviral effect (e.g. adefovir), if the response remains partial or becomes inadequate at week 48 , a change in therapy should be undertaken unless HBV DNA has been decreasing steadily and is nearly undetectable.

Recently, there have been efforts to prevent resistance in NA-experienced patients. Seventy-two patients, who received lamivudine therapy for over 6 months, were still positive for HBV DNA ( $\geq 300$ copies $/ \mathrm{ml}$ ) and had no lamivudine-related mutation, were randomized into switching to entecavir $1 \mathrm{mg}$ or maintaining lamivudine therapy. In a preliminary report of 34 patients who completed 48 weeks of therapy, $82 \%$ patients showed undetectable HBV DNA $(<300$ copies $/ \mathrm{ml})$ in the entecavirswitched group; in contrast, only $12 \%$ patients in the lamivudine-maintained group achieved undetectable HBV DNA at week 48. In the lamivudine-maintained group, genotypic resistance occurred in $64.7 \%$ at week 48 [56]. However, no genetic resistance was observed in the entecavir-switched group. The final results of 96 weeks of therapy are awaited. Therefore, in a suboptimal response group, clinical efficacy of switching to more potent, especially non-cross-resistant, antiviral agents should be validated soon.

\section{Management of Antiviral Resistance}

During NA therapy, the first manifestation of antiviral resistance is the detection of resistant mutations (genotypic resistance). Resistant mutations may be detected at the same time or prior to virologic breakthrough. With time, serum HBV DNA levels continue to increase (viral rebound) and biochemical breakthrough develops [1]. During these serial changes, physicians should decide at which time point to change antiviral therapy.

Management of antiviral resistance has been well established by several important concepts that have emerged in recent years. In a study [57] to assess whether the timing of rescue therapy influenced virological outcome in lamivudine-resistant $\mathrm{HBeAg}$-negative $\mathrm{CHB}$ patients $(n=74)$, combination therapy of lamivudine and adefovir was initiated either at the time of genotypic resistance (defined as levels of HBV DNA $\leq 3-6 \log _{10}$ copies/ml and persistently normal ALT levels) and phenotypic resistance (defined as levels of HBV DNA $>6 \log _{10}$ copies/ml and biochemical breakthrough). The 2-year rates of virological response (HBV DNA $<2,000$ copies/ $\mathrm{ml}$ ) were $100 \%$ in the former patients and $78 \%$ in the lat- 
ter ones. In HBeAg-positive CHB patients $(\mathrm{n}=207)$ with lamivudine resistance [58], virological response was inversely correlated with HBV DNA levels before the initiation of rescue therapy with adefovir ( \pm lamivudine). In patients with low viremia (HBV DNA $<5 \log _{10}$ copies/ $\mathrm{ml}$ ), early virological response (HBV DNA $<50$ copies $/ \mathrm{ml}$ at 6 months) occurred in 94\%; in contrast, it occurred only in $4.1 \%$ of patients with high virus levels $\left(>8 \log _{10}\right.$ copies $/ \mathrm{ml}$ ). Therefore, to optimize antiviral treatment in NA-resistant patients, rescue therapy should be initiated at the time of virologic breakthrough, which is the first clinical parameter for resistance.

The second emerging concept is a combination or switching strategy in NA-resistant patients. Two randomized controlled trials have addressed this issue [59, $60]$. In the first randomized controlled study with lamivudine-resistant patients (56 HBeAg positive and $2 \mathrm{HBeAg}$ negative) [59], combination therapy with lamivudine + adefovir did not show any differences in the level of suppression of HBV DNA at 12 months compared with adefovir monotherapy. No adefovir resistance was observed at 12 months. Therefore, for several years, adefovir monotherapy had been widely used in lamivudine-resistant patients during clinical practice. However, in a study involving $95 \mathrm{HBeAg}$-positive lamivudine-resistant patients treated with adefovir for 48 weeks, the emergence of adefovir resistance was more common in lamivudine-resistant patients (18\%) than in those who were treatment naive (0\%) [61]. Chen et al. [62] also showed a high incidence of adefovir resistance at month 24 (38.3\%) in lamivudineresistant patients. Several recent studies have suggested that combining lamivudine with adefovir, compared with sequential monotherapy, is associated with an improvement in virological response and a lower rate of resistance in patients with lamivudine resistance $[60,63]$. In a retrospective analysis of 588 lamivudine-resistant patients, 285 patients had had adefovir added in combination with lamivudine and 303 had been switched to adefovir [63]. The rates of virological response were similar in both the combined and switched groups after 3 years of therapy ( 78 vs. $71 \%$, respectively). However, the rate of virologic breakthrough (6 vs. 30\%) and genotypic resistance to adefovir ( 0 vs.16\%) were significantly higher in the switched group compared to the combination group. In a subsequent small randomized controlled trial in $\mathrm{HBeAg}$-negative lamivudine-resistant patients, who were treated by being switched to adefovir monotherapy or combination of adefovir with lamivudine, the virological and biochemical response rates were similar with both strategies, but adefovir resistance occurred in $21 \%$
Table 3. Summary of drug susceptibility for most frequent HBV mutants

\begin{tabular}{|c|c|c|c|c|c|}
\hline \multirow[t]{3}{*}{ HBV variants } & \multicolumn{5}{|c|}{ Susceptibility } \\
\hline & \multicolumn{3}{|c|}{$\begin{array}{l}\text { nucleoside } \\
\text { analogs }\end{array}$} & \multicolumn{2}{|c|}{$\begin{array}{l}\text { nucleotide } \\
\text { analogs }\end{array}$} \\
\hline & $\begin{array}{l}\text { lamiv- } \\
\text { udine }\end{array}$ & $\begin{array}{l}\text { telbiv- } \\
\text { udine }\end{array}$ & $\begin{array}{l}\text { ente- } \\
\text { cavir }\end{array}$ & $\begin{array}{l}\text { adefo- } \\
\text { vir }\end{array}$ & $\begin{array}{l}\text { teno- } \\
\text { fovir }\end{array}$ \\
\hline Wild-type & S & S & S & $\mathrm{S}$ & $\mathrm{S}$ \\
\hline M204V/I ( \pm L180M) & $\mathrm{R}$ & $\mathrm{R}$ & I & S & S \\
\hline $\mathrm{A} 181 \mathrm{~T} / \mathrm{V}$ & $\mathrm{R}$ & I & S & $\mathrm{R}$ & $\mathrm{S}$ \\
\hline $\mathrm{N} 236 \mathrm{~T}$ & S & S & S & $\mathrm{R}$ & I \\
\hline $\mathrm{I} 169 \mathrm{~T}+\mathrm{M} 250 \mathrm{~V}+\mathrm{M} 204 \mathrm{~V} / \mathrm{I}$ & $\mathrm{R}$ & $\mathrm{R}$ & $\mathrm{R}$ & S & $\mathrm{S}$ \\
\hline T184G+S202I+M204V/I & $\mathrm{R}$ & $\mathrm{R}$ & $\mathrm{R}$ & S & S \\
\hline A194T & $\mathrm{R}$ & S & S & NA & $\mathrm{R}$ \\
\hline
\end{tabular}

$\mathrm{S}=$ Sensitive; $\mathrm{I}$ = intermediate $\mathrm{R}$ = resistant $\mathrm{NA}$ = not available.

Adapted from references [51, 73].

of patients who were switched to adefovir monotherapy within 15-18 months of treatment compared to $0 \%$ in patients receiving add-on combination therapy [60]. In addition, long-term response to add-on therapy showed excellent virological outcomes and safety. The cumulative rate of virological response, genotypic resistance and virologic breakthrough, were 82,4 , and $0 \%$ at 4 years, respectively [64]. These findings suggest that add-on combination strategy in lamivudine-resistant patients is very effective in suppressing viral replication and emergence of resistance.

We are now facing the emergence of adefovir- or entecavir-resistant virus. However, there have been no well designed studies to address the issue of add-on combination or switching strategy. Nonetheless, the lessons learned from the lamivudine resistance support the use of combination therapy in patients with other drug-resistant HBV. In a retrospective study by Yang et al. [65], out of $40 \mathrm{CHB}$ patients with sequential resistance to lamivudine-adefovir, 13 patients received combination therapy of adefovir + lamivudine and 27 were switched to entecavir (1 mg) monotherapy. In patients who were switched to entecavir, the virologic breakthrough rate was $55 \%$ at 18 months. In contrast, in the combination group, the virologic breakthrough rate was $0 \%$. This study also supports the use of combination therapy in NA-resistant patients.

Generally, nucleoside analogs (lamivudine, telbivudine, emtricitabine, entecavir) are still sensitive to resis- 
Table 4. Treatment guidelines for the patients with antiviral-resistant $\operatorname{HBV}[1,12,51]$

\begin{tabular}{|c|c|c|c|}
\hline Resistance to & AASLD 2007 & Panel of US hepatologists 2008 & EASL 2009 \\
\hline $\begin{array}{l}\text { Lamivudine } \\
\text { (LMV) }\end{array}$ & $\begin{array}{l}\text { Add ADV or TDF. } \\
\text { Stop LMV, switch to Truvada. } \\
\text { Stop LMV, switch to ETV. }\end{array}$ & $\begin{array}{l}\text { Add ADV or TDF. } \\
\text { Switch to Truvada. }\end{array}$ & Add TDF (add ADV if TDF not yet available). \\
\hline $\begin{array}{l}\text { Telbivudine } \\
\text { (LdT) }\end{array}$ & $\begin{array}{l}\text { Add ADV or TDF. } \\
\text { Stop LdT, switch to Truvada. } \\
\text { Stop LdT, switch to ETV. }\end{array}$ & $\begin{array}{l}\text { Add ADV or TDF. } \\
\text { Switch to Truvada. }\end{array}$ & Add TDF (add ADV if TDF not yet available). \\
\hline $\begin{array}{l}\text { Entecavir } \\
(\mathrm{ETV})\end{array}$ & $\begin{array}{l}\text { Switch to or add ADV. } \\
\text { Switch to or add TDF. }\end{array}$ & $\begin{array}{l}\text { Switch to or add ADV or TDF. } \\
\text { Switch to Truvada. }\end{array}$ & Add TDF. \\
\hline $\begin{array}{l}\text { Adefovir } \\
(\mathrm{ADV})\end{array}$ & $\begin{array}{l}\text { Add LMV. } \\
\text { Stop ADV, switch to Truvada. } \\
\text { Switch to or add ETV. }\end{array}$ & $\begin{array}{l}\text { Add LMV or LdT. } \\
\text { Switch to or add ETV } \\
\text { (if no prior LMV resistance). } \\
\text { Switch to Truvada. }\end{array}$ & $\begin{array}{l}\text { It is recommended to switch to TDF, if available, } \\
\text { and add a second drug without cross resistance. } \\
\text { If an N236T is present, add LMV, ETV or LdT } \\
\text { or switch to Truvada. } \\
\text { If an A181T/V is present, add ETV or switch to } \\
\text { Truvada. }\end{array}$ \\
\hline $\begin{array}{l}\text { Tenofovir } \\
\text { (TDF) }\end{array}$ & Not mentioned. & Not mentioned. & $\begin{array}{l}\text { TDF resistance has not been described. } \\
\text { It is recommended to perform genotyping and } \\
\text { phenotyping to determine } \\
\text { the cross-resistance profile. ETV, LdT, LMV } \\
\text { or emtricitabine could be added. }\end{array}$ \\
\hline
\end{tabular}

Pre-existing LMV-resistant mutation predisposes to entecavir resistance. Truvada is a combination pill with emtricitabine $200 \mathrm{mg}$ and TDF $300 \mathrm{mg} .{ }^{\text {a }}$ TDF might be preferred over ADV as the add-on agent. AASLD = American Association for the study of the liver; $\mathrm{EASL}=$ European Association for the study of the liver.

tant virus to nucleotide analogs (adefovir, tenofovir) and vice versa (table 2). Therefore, in any NA-resistant patients, add-on combination therapy should be chosen from a nucleoside analog with a nucleotide analog based on an in vitro susceptibility test (table 3 ), if there are no available clinical study results.

Tenofovir disoproxil fumarate, a nucleotide analog that is structurally closely related to adefovir [66], has recently been approved for the treatment of CHB. Even though it was initially developed and approved for HIV, it has potent antiviral activity against wild-type or lamivudine-resistant HBV strains both in vitro and in clinical trials [22, 67-69]. In a comparative study of 53 patients with lamivudine resistance, 35 received tenofovir therapy and the remaining 18 received adefovir monotherapy. Virological response $(<300$ copies/ml) at week 48 was $100 \%$ in tenofovir-treated patients and $44 \%$ with adefovir therapy. No genotypic resistance was observed during the follow-up of 130 weeks [68]. Therefore, we can speculate that tenofovir-based combination therapy in nucleoside analog-resistant patients can achieve better virological outcome than adefovir-based combination therapy, even though the safety of this combination is unknown. Recent guidelines prefer to recommend tenofovir-based combination therapy to adefovir-based combination therapy in nucleoside analog-resistant patients (table 4).

\section{Conclusion}

Even though NAs are very effective in suppressing HBV replication, long-term therapy with NAs is associated with the development of antiviral drug resistance. Therefore, to prevent this resistance, development of antiviral agents that act with a different mechanism and at a different site, which is the paradigm of combination therapy for HIV management, is needed. However, such antiviral agents are unlikely to become available in the near future. Therefore, an understanding of the molecular basis of NAs resistance and optimal use of NAs is important for the time being. To minimize the emergence of drug resistance using current available antiviral agents, physicians should avoid unnecessary therapy. Once anti- 
viral treatment is initiated, the aim should be to suppress viral replication as quickly and completely as possible. Continuous surveillance for drug resistance should be conducted. However, once antiviral resistance develops, prompt combination therapy should be initiated.

\section{Disclosure Statement}

The authors declare that there is no conflict of interest regarding this study.

\section{References}

1 Lok AS, McMahon BJ: Chronic hepatitis B. Hepatology 2007;45:507-539.

- 2 Chen CJ, Yang HI, Su J, Jen CL, You SL, Lu SN, Huang GT, Iloeje UH: Risk of hepatocellular carcinoma across a biological gradient of serum hepatitis B virus DNA level. JAMA 2006;295:65-73.

-3 Iloeje UH, Yang HI, Jen CL, Su J, Wang LY, You SL, Chen CJ: Risk and predictors of mortality associated with chronic hepatitis B infection. Clin Gastroenterol Hepatol 2007;5: 921-931.

4 Iloeje UH, Yang HI, Su J, Jen CL, You SL, Chen CJ: Predicting cirrhosis risk based on the level of circulating hepatitis B viral load. Gastroenterology 2006;130:678-686.

5 Liaw YF, Sung JJ, Chow WC, Farrell G, Lee CZ, Yuen H, Tanwandee T, Tao QM, Shue K, Keene ON, Dixon JS, Gray DF, Sabbat J: Lamivudine for patients with chronic hepatitis $B$ and advanced liver disease. N Engl J Med 2004;351:1521-1531.

-6 Yuen MF, Seto WK, Chow DH, Tsui K, Wong DK, Ngai VW, Wong BC, Fung J, Yuen JC, Lai CL: Long-term lamivudine therapy reduces the risk of long-term complications of chronic hepatitis B infection even in patients without advanced disease. Antivir Ther 2007;12:1295-1303.

7 Lok AS, McMahon BJ: Chronic hepatitis B: update of recommendations. Hepatology 2004:39:857-861.

-8 Liaw YF, Leung N, Guan R, Lau GK, Merican I, McCaughan G, Gane E, Kao JH, Omata M: Asian-pacific consensus statement on the management of chronic hepatitis B: a 2005 update. Liver Int 2005;25:472-489.

$\checkmark 9$ Keeffe EB, Dieterich DT, Han SH, Jacobson IM, Martin P, Schiff ER, Tobias H, Wright TL: A treatment algorithm for the management of chronic hepatitis B virus infection in the United States: an update. Clin Gastroenterol Hepatol 2006;4:936-962.

10 Hoofnagle JH, Doo E, Liang TJ, Fleischer R, Lok AS: Management of hepatitis B: summary of a clinical research workshop. Hepatology 2007;45:1056-1075.

-11 Lee KS, Kim DJ: Management of chronic hepatitis B. Kor J Hepatol 2007;13:447-488.

-12 Keeffe EB, Dieterich DT, Han SH, Jacobson IM, Martin P, Schiff ER, Tobias H: A treatment algorithm for the management of chronic hepatitis B virus infection in the United States: 2008 update. Clin Gastroenterol Hepatol 2008;12:1315-1341.
13 Dienstag JL, Cianciara J, Karayalcin S, Kowdley KV, Willems B, Plisek S, Woessner M, Gardner S, Schiff E: Durability of serologic response after lamivudine treatment of chronic hepatitis B. Hepatology 2003;37: 748-755.

14 Lok AS, Lai CL, Leung N, Yao GB, Cui ZY, Schiff ER, Dienstag JL, Heathcote EJ, Little NR, Griffiths DA, Gardner SD, Castiglia M: Long-term safety of lamivudine treatment in patients with chronic hepatitis B. Gastroenterology 2003;125:1714-1722.

15 Andreone P, Gramenzi A, Cursaro C, Biselli M, Camma C, Trevisani F, Bernardi M: High risk of hepatocellular carcinoma in anti-HBe positive liver cirrhosis patients developing lamivudine resistance. J Viral Hepat 2004; 11:439-442.

16 Chang TT, Gish RG, de Man R, Gadano A, Sollano J, Chao YC, Lok AS, Han KH, Goodman Z, Zhu J, Cross A, DeHertogh D, Wilber R, Colonno R, Apelian D: A comparison of entecavir and lamivudine for HBeAg-positive chronic hepatitis B. N Engl J Med 2006; 354:1001-1010.

17 Dienstag JL, Schiff ER, Wright TL, Perrillo RP, Hann HW, Goodman Z, Crowther L, Condreay LD, Woessner M, Rubin M, Brown NA: Lamivudine as initial treatment for chronic hepatitis B in the United States. N Engl J Med 1999;341:1256-1263.

18 Lai CL, Chien RN, Leung NW, Chang TT, Guan R, Tai DI, Ng KY, Wu PC, Dent JC, Barber J, Stephenson SL, Gray DF: A oneyear trial of lamivudine for chronic hepatitis B. Asia Hepatitis Lamivudine Study Group. N Engl J Med 1998;339:61-68.

$\checkmark 19$ Lai CL, Gane E, Liaw YF, Hsu CW, Thongsawat S, Wang Y, Chen Y, Heathcote EJ, Rasenack J, Bzowej N, Naoumov NV, Di Bisceglie AM, Zeuzem S, Moon YM, Goodman Z, Chao G, Constance BF, Brown NA Telbivudine versus lamivudine in patients with chronic hepatitis B. N Engl J Med 2007; 357:2576-2588.

20 Lai CL, Shouval D, Lok AS, Chang TT, Cheinquer H, Goodman Z, DeHertogh D, Wilber R, Zink RC, Cross A, Colonno R, Fernandes L: Entecavir versus lamivudine for patients with HBeAg-negative chronic hepatitis B. N Engl J Med 2006;354:1011-1020.
21 Marcellin P, Chang TT, Lim SG, Tong MJ, Sievert W, Shiffman ML, Jeffers L, Goodman Z, Wulfsohn MS, Xiong S, Fry J, Brosgart CL: Adefovir dipivoxil for the treatment of hepatitis B e antigen-positive chronic hepatitis B. N Engl J Med 2003;348:808-816.

22 Marcellin P, Heathcote EJ, Buti M, Gane E, de Man RA, Krastev Z, Germanidis G, Lee SS, Flisiak R, Kaita K, Manns M, Kotzev I, Tchernev K, Buggisch P, Weilert F, Kurdas OO, Shiffman ML, Trinh H, Washington MK, Sorbel J, Anderson J, Snow-Lampart A, Mondou E, Quinn J, Rousseau F: Tenofovir disoproxil fumarate versus adefovir dipivoxil for chronic hepatitis B. N Engl J Med 2008;359:2442-2455.

23 Hadziyannis SJ, Tassopoulos NC, Heathcote EJ, Chang TT, Kitis G, Rizzetto M, Marcellin P, Lim SG, Goodman Z, Wulfsohn MS, Xiong S, Fry J, Brosgart CL: Adefovir dipivoxil for the treatment of hepatitis B e antigen-negative chronic hepatitis b. N Engl J Med 2003;348:800-807.

-24 Mommeja-Marin H, Mondou E, Blum MR, Rousseau F: Serum HBV DNA as a marker of efficacy during therapy for chronic $\mathrm{HBV}$ infection: analysis and review of the literature. Hepatology 2003;37:1309-1319.

25 Schiff ER, Lai CL, Hadziyannis S, Neuhaus P, Terrault N, Colombo M, Tillmann HL, Samuel D, Zeuzem S, Lilly L, Rendina M, Villeneuve JP, Lama N, James C, Wulfsohn MS, Namini H, Westland C, Xiong S, Choy GS, Van Doren S, Fry J, Brosgart CL: Adefovir dipivoxil therapy for lamivudine-resistant hepatitis B in pre- and post-liver transplantation patients. Hepatology 2003;38: 1419-1427.

26 Lok AS, Zoulim F, Locarnini S, Bartholomeusz A, Ghany MG, Pawlotsky JM, Liaw YF, Mizokami M, Kuiken C: Antiviral drug-resistant HBV: standardization of nomenclature and assays and recommendations for management. Hepatology 2007;46: 254-265.

27 Pawlotsky JM, Dusheiko G, Hatzakis A, Lau D, Lau G, Liang TJ, Locarnini S, Martin P, Richman DD, Zoulim F: Virologic monitoring of hepatitis B virus therapy in clinical trials and practice: recommendations for a standardized approach. Gastroenterology 2008;134:405-415. 
28 Hulgan T, Haas DW: Toward a pharmacogenetic understanding of nucleotide and nucleoside analogue toxicity. J Infect Dis 2006; 194:1471-1474.

29 Lai CL, Leung N, Teo EK, Tong M, Wong F, Hann HW, Han S, Poynard T, Myers M, Chao G, Lloyd D, Brown NA: A 1-year trial of telbivudine, lamivudine, and the combination in patients with hepatitis $B$ e antigenpositive chronic hepatitis B. Gastroenterology 2005;129:528-536.

- 30 Liaw YF, Gane E, Leung N, Zeuzem S, Wang Y, Lai CL, Heathcote EJ, Manns M, Bzowej N, Niu J, Han SH, Hwang SG, Cakaloglu Y, Tong MJ, Papatheodoridis G, Chen Y, Brown NA, Albanis E, Galil K, Naoumov NV: Twoyear globe trial results: telbivudine is superior to lamivudine in patients with chronic hepatitis B. Gastroenterology 2009;136:486495.

- 31 Hadziyannis SJ, Tassopoulos NC, Heathcote EJ, Chang TT, Kitis G, Rizzetto M, Marcellin P, Lim SG, Goodman Z, Ma J, Brosgart CL, Borroto-Esoda K, Arterburn S, Chuck SL: Long-term therapy with adefovir dipivoxil for HBeAg-negative chronic hepatitis B for up to 5 years. Gastroenterology 2006;131: 1743-1751.

-32 Chang TT, Gish RG, Hadziyannis SJ, Cianciara J, Rizzetto M, SchiffER, Pastore G, Bacon BR, Poynard T, Joshi S, Klesczewski KS, Thiry A, Rose RE, Colonno RJ, Hindes RG: A dose-ranging study of the efficacy and tolerability of entecavir in lamivudine-refractory chronic hepatitis B patients. Gastroenterology 2005;129:1198-1209.

-33 Delaney WE 4th, Yang H, Westland CE, Das K, Arnold E, Gibbs CS, Miller MD, Xiong S: The hepatitis $B$ virus polymerase mutation $\mathrm{rtV} 173 \mathrm{~L}$ is selected during lamivudine therapy and enhances viral replication in vitro. J Virol 2003;77:11833-11841.

-34 Ono SK, Kato N, Shiratori Y, Kato J, Goto T, Schinazi RF, Carrilho FJ, Omata M: The polymerase L528M mutation cooperates with nucleotide binding-site mutations, increasing hepatitis B virus replication and drug resistance. J Clin Invest 2001;107:449455 .

35 Warner N, Locarnini S, Kuiper M, Bartholomeusz A, Ayres A, Yuen L, Shaw T: The rtL80I substitution in the hepatitis $\mathrm{B}$ virus polymerase is associated with lamivudine resistance and enhanced viral replication in vitro. Antimicrob Agents Chemother 2007.

- 36 Allen MI, Deslauriers M, Andrews CW, Tipples GA, Walters KA, Tyrrell DL, Brown N, Condreay LD: Identification and characterization of mutations in hepatitis B virus resistant to lamivudine. Lamivudine Clinical Investigation Group. Hepatology 1998;27: 1670-1677.

- 37 Liaw YF, Chien RN, Yeh CT, Tsai SL, Chu CM: Acute exacerbation and hepatitis B virus clearance after emergence of YMDD motif mutation during lamivudine therapy. Hepatology 1999;30:567-572.
38 Yuen MF, Kato T, Mizokami M, Chan AO, Yuen JC, Yuan HJ, Wong DK, Sum SM, Ng IO, Fan ST, Lai CL: Clinical outcome and virologic profiles of severe hepatitis B exacerbation due to YMDD mutations. J Hepatol 2003;39:850-855.

39 Chen CH, Lee CM, Lu SN, Wang JH, Tung HD, Hung CH, Chen WJ, Changchien CS: Comparison of clinical outcome between patients continuing and discontinuing lamivudine therapy after biochemical breakthrough of YMDD mutants. J Hepatol 2004; 41:454-461.

40 Ghany MG, Doo EC: Antiviral resistance and hepatitis B therapy. Hepatology 2009;49: S174-S184.

41 Ghany M, Liang TJ: Drug targets and molecular mechanisms of drug resistance in chronic hepatitis B. Gastroenterology 2007; 132:1574-1585.

42 Nowak MA, Bonhoeffer S, Hill AM, Boehme $\mathrm{R}$, Thomas HC, McDade H: Viral dynamics in hepatitis B virus infection. Proc Natl Acad Sci USA 1996;93:4398-4402.

43 Locarnini S: Molecular virology and the development of resistant mutants: Implications for therapy. Semin Liver Dis 2005;25(suppl 1):9-19.

44 Richman DD: The implications of drug resistance for strategies of combination antiviral chemotherapy. Antiviral Res 1996;29:3133.

45 Melegari M, Scaglioni PP, Wands JR: Hepatitis B virus mutants associated with $3 \mathrm{TC}$ and famciclovir administration are replication defective. Hepatology 1998;27:628633.

46 Tenney DJ, Levine SM, Rose RE, Walsh AW Weinheimer SP, Discotto L, Plym M, Pokornowski K, Yu CF, Angus P, Ayres A, Bartholomeusz A, Sievert W, Thompson G, Warner N, Locarnini S, Colonno RJ: Clinical emergence of entecavir-resistant hepatitis B virus requires additional substitutions in virus already resistant to lamivudine. Antimicrob Agents Chemother 2004;48:3498-3507.

47 Tenney DJ, Rose RE, Baldick CJ, Pokornowski KA, Eggers BJ, Fang J, Wichroski MJ, Xu D, Yang J, Wilber RB, Colonno RJ: Longterm monitoring shows hepatitis B virus resistance to entecavir in nucleoside-naive patients is rare through 5 years of therapy. Hepatology 2009;49:1503-1514.

48 Yim HJ, Lok AS: Natural history of chronic hepatitis B virus infection: what we knew in 1981 and what we know in 2005. Hepatology 2006;43:S173-S181.

49 Andreani T, Serfaty L, Mohand D, Dernaika S, Wendum D, Chazouilleres O, Poupon R: Chronic hepatitis $\mathrm{B}$ virus carriers in the immunotolerant phase of infection: histologic findings and outcome. Clin Gastroenterol Hepatol 2007;5:636-641.
50 Keeffe EB, Dieterich DT, Han SH, Jacobson IM, Martin P, Schiff ER, Tobias H: A treatment algorithm for the management of chronic hepatitis B virus infection in the United States: 2008 update. Clin Gastroenterol Hepatol 2008;6:1315-1341; quiz 1286.

51 European Association for the Study of the Liver: EASL Clinical Practice Guidelines: management of chronic hepatitis B. J Hepatol 2009;50:227-242.

52 Ribeiro RM, Lo A, Perelson AS: Dynamics of hepatitis $B$ virus infection. Microbes Infect 2002;4:829-835.

53 Yuen MF, Sablon E, Hui CK, Yuan HJ, Decraemer H, Lai CL: Factors associated with hepatitis B virus DNA breakthrough in patients receiving prolonged lamivudine therapy. Hepatology 2001;34:785-791.

54 Sherman M, Yurdaydin C, Sollano J, Silva M, Liaw YF, Cianciara J, Boron-Kaczmarska A, Martin P, Goodman Z, Colonno R, Cross A, Denisky G, Kreter B, Hindes R: Entecavir for treatment of lamivudine-refractory, $\mathrm{HBeAg}$ positive chronic hepatitis B. Gastroenterology 2006;130:2039-2049.

-55 Keeffe EB, Zeuzem S, Koff RS, Dieterich DT, Esteban-Mur R, Gane EJ, Jacobson IM, Lim SG, Naoumov N, Marcellin P, Piratvisuth T, Zoulim F: Report of an international workshop: roadmap for management of patients receiving oral therapy for chronic hepatitis B. Clin Gastroenterol Hepatol 2007;5:890897.

56 Park JY, Ahn SH, Kim DY, Cho M, Han KH, Lee HJ, Tak YY, Um SH, Heo J: Randomized, open-labelled study evaluating the antiviral efficacy, safety, and tolerability of continuing lamivudine therapy or switching to entecavir in subjects with chronic hepatitis B with detectable HBV DNA (HBV DNA > 60 $\mathrm{IU} / \mathrm{ml}$ by PCR) while on lamivudine for at least 6 months: interim analysis at 48 weeks. Kor J Hepatol 2009;15:S44

57 Lampertico P, Vigano M, Manenti E, Iavarone $\mathrm{M}$, Lunghi $\mathrm{G}$, Colombo M: Adefovir rapidly suppresses hepatitis b in $\mathrm{HBeAg}$ negative patients developing genotypic resistance to lamivudine. Hepatology 2005;42: 1414-1419.

58 Shin SR, Koh KC, Jung HY, Gwak GY, Choi MS, Lee JH, Paik SW, Yoo BC: The DNA levels on initiation of adefovir as the important factor to get the more initial virological response in patients with lamivudine resistant hepatitis B. Hepatology 2008;48:738A.

59 Peters MG, Hann Hw H, Martin P, Heathcote EJ, Buggisch P, Rubin R, Bourliere M, Kowdley K, Trepo C, Gray Df D, Sullivan M, Kleber K, Ebrahimi R, Xiong S, Brosgart CL: Adefovir dipivoxil alone or in combination with lamivudine in patients with lamivudine-resistant chronic hepatitis B. Gastroenterology 2004;126:91-101. 
-60 Rapti I, Dimou E, Mitsoula P, Hadziyannis SJ: Adding-on versus switching-to adefovir therapy in lamivudine-resistant $\mathrm{HBeAg-}$ negative chronic hepatitis $\mathrm{B}$. Hepatology 2007;45:307-313.

-61 Lee YS, Suh DJ, Lim YS, Jung SW, Kim KM, Lee HC, Chung YH, Lee YS, Yoo W, Kim SO: Increased risk of adefovir resistance in patients with lamivudine-resistant chronic hepatitis B after 48 weeks of adefovir dipivoxil monotherapy. Hepatology 2006;43: 1385-1391.

62 Chen CH, Wang JH, Lee CM, Hung CH, Hu TH, Wang JC, Lu SN, Changchien CS: Virological response and incidence of adefovir resistance in lamivudine-resistant patients treated with adefovir dipivoxil. Antivir Ther 2006;11:771-778.

63 Lampertico P, Marzano A, Levrero M, Manenti E, Iavarone M, Lunghi G, Colombo M: Adefovir monotherapy for lamivudine resistant patients with $\mathrm{HBeAg}$-negative chronic hepatitis B. Hepatology 2006;44:693A.

-64 Lampertico P, Vigano M, Manenti E, Iavarone $\mathrm{M}$, Sablon E, Colombo M: Low resistance to adefovir combined with lamivudine: a 3-year study of 145 lamivudine-resistant hepatitis B patients. Gastroenterology 2007;133:1445-1451.
65 Yang HJ, Lee JH, Kim YJ, Yoon JH, Lee HS: Lamivudine and adefovir dipivoxil versus entecavir $1.0 \mathrm{mg}$ alone for the treatment of adefovir-resistant mutation which developed during sequential adefovir monotherapy in patients with lamivudine-resistant chronic hepatitis B. Kor J Hepatol 2009; 15: S50.

66 Shaw T, Bartholomeusz A, Locarnini S: HBV drug resistance: mechanisms, detection and interpretation. J Hepatol 2006;44:593-606.

67 Marcellin P, Buti M, Krastev Z, Gurel S, Balabanska RI, Dusheiko G: Two year tenofovir disoproxil fumarate (TDF) treatment and adefovir dipivoixil switch data in $\mathrm{HBeAg}$ negative patients with chronic hepatitis $B$ (study 102), preliminary analysis. Hepatology 2008;48:370A.

68 van Bommel F, Wunsche T, Mauss S, Reinke P, Bergk A, Schurmann D, Wiedenmann B, Berg T: Comparison of adefovir and tenofovir in the treatment of lamivudine-resistant hepatitis B virus infection. Hepatology 2004; 40:1421-1425.

69 van Bommel F, Zollner B, Sarrazin C, Spengler U, Huppe D, Moller B, Feucht HH, Wiedenmann B, Berg T: Tenofovir for patients with lamivudine-resistant hepatitis B virus (HBV) infection and high HBV DNA level during adefovir therapy. Hepatology 2006; 44:318-325.

70 Lau GK, Piratvisuth T, Luo KX, Marcellin P, Thongsawat S, Cooksley G, Gane E, Fried MW, Chow WC, Paik SW, Chang WY, Berg T, Flisiak R, McCloud P, Pluck N: Peginterferon alfa-2a, lamivudine, and the combination for HBeAg-positive chronic hepatitis B. N Engl J Med 2005;352:2682-2695.
71 Marcellin P, Lau GK, Bonino F, Farci P, Hadziyannis S, Jin R, Lu ZM, Piratvisuth T, Germanidis G, Yurdaydin C, Diago M, Gurel S, Lai MY, Button P, Pluck N: Peginterferon alfa-2a alone, lamivudine alone, and the two in combination in patients with $\mathrm{HBeAg-neg-}$ ative chronic hepatitis B. N Engl J Med 2004; 351:1206-1217.

72 Lim SG, Ng TM, Kung N, Krastev Z, Volfova M, Husa P, Lee SS, Chan S, Shiffman ML, Washington MK, Rigney A, Anderson J, Mondou E, Snow A, Sorbel J, Guan R, Rousseau F: A double-blind placebo-controlled study of emtricitabine in chronic hepatitis B. Arch Intern Med 2006;166:49-56.

73 Amini-Bavil-Olyaee S, Herbers U, Sheldon J, Luedde T, Trautwein C, Tacke F: The rtA194T polymerase mutation impacts viral replication and susceptibility to tenofovir in hepatitis B e antigen-positive and hepatitis B e antigen-negative hepatitis B virus strains. Hepatology 2009;49:1158-1165.

$>74$ Angus P, Vaughan R, Xiong S, Yang H, Delaney W, Gibbs C, Brosgart C, Colledge D, Edwards R, Ayres A, Bartholomeusz A, Locarnini S: Resistance to adefovir dipivoxil therapy associated with the selection of a novel mutation in the HBV polymerase. Gastroenterology 2003;125:292-297. 